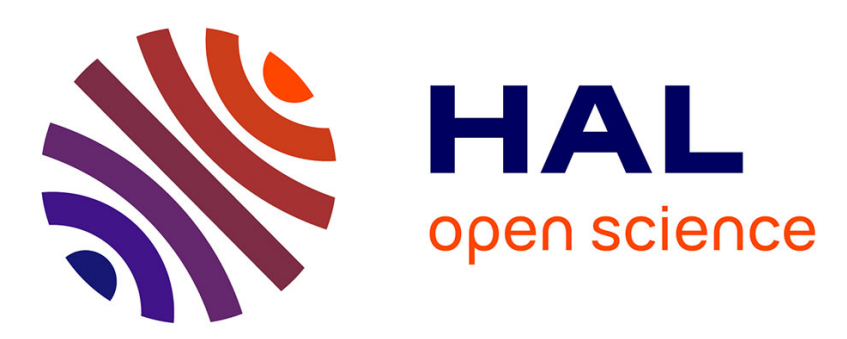

\title{
Prediction of nutrient flows with potential impacts on the environment in a rabbit farm: a modelling approach
}

Bertrand Méda, Laurence Lamothe, Mélynda Hassouna

\section{To cite this version:}

Bertrand Méda, Laurence Lamothe, Mélynda Hassouna. Prediction of nutrient flows with potential impacts on the environment in a rabbit farm: a modelling approach. Animal Production Science, 2014, 54 (11-12), pp.2042-2051. 10.1071/an14530 . hal-01209230

\section{HAL Id: hal-01209230 \\ https://hal.science/hal-01209230}

Submitted on 27 May 2020

HAL is a multi-disciplinary open access archive for the deposit and dissemination of scientific research documents, whether they are published or not. The documents may come from teaching and research institutions in France or abroad, or from public or private research centers.
L'archive ouverte pluridisciplinaire HAL, est destinée au dépôt et à la diffusion de documents scientifiques de niveau recherche, publiés ou non, émanant des établissements d'enseignement et de recherche français ou étrangers, des laboratoires publics ou privés. 


\title{
Prediction of nutrient flows with potential impacts on the environment in a rabbit farm: a modelling approach
}

\author{
Bertrand Méda $^{\mathrm{A}, \mathrm{G}}$, Laurence Fortun-Lamothe ${ }^{\mathrm{B}, \mathrm{C}, \mathrm{D}}$ and Mélynda Hassouna ${ }^{\mathrm{E}, \mathrm{F}}$ \\ AINRA, UR83 Recherches Avicoles, F-37380 Nouzilly, France. \\ ${ }^{B}$ INRA, UMR1388 Génétique Physiologie et Systèmes d’Elevage, F-31326 Castanet-Tolosan, France. \\ CUniversité de Toulouse INPT ENVT, UMR1388 Génétique, Physiologie et Systèmes d'Elevage, \\ F-31076 Toulouse, France. \\ DUniversité de Toulouse INPT ENSAT, UMR1388 Génétique, Physiologie et Systèmes d'Elevage, \\ F-31326 Castanet-Tolosan, France. \\ EINRA, UMR1069 Sol Agro et hydrosystème Spatialisation, F-35000 Rennes, France. \\ ${ }^{\mathrm{F}}$ Agrocampus Ouest, F-35000 Rennes, France. \\ ${ }^{\mathrm{G}}$ Corresponding author. Email: bertrand.meda@tours.inra.fr
}

\begin{abstract}
To face the increasing demand for animal products throughout the world, livestock-farming systems have been intensified. This intensification has proven to be economically effective but is noted for its negative impact on the environment through the production of ammonia $\left(\mathrm{NH}_{3}\right)$ and the greenhouse gases nitrous oxide $\left(\mathrm{N}_{2} \mathrm{O}\right)$ and methane. In this context, dynamic models are useful tools to evaluate the effects of farming practice on nutrient flows and losses to the environment. This paper presents the development of a model simulating the flows of nitrogen $(\mathrm{N})$ and phosphorus $(\mathrm{P})$ in a rabbit production farm. The model is comprised of two submodels. The first submodel simulates the number of animals in the farm (births, deaths, culling of does/fatteners) and their respective performances (growth, feed intake, milk production). The second one simulates the excretion of $\mathrm{N}$ and $\mathrm{P}$ for each animal category using a mass-balance approach between intake (feed and/or milk intake) and exports (body deposition, milk production, gestation). Specific emission factors are then applied to the excreted $\mathrm{N}$ amounts to estimate total $\mathrm{N}, \mathrm{NH}_{3}$ and $\mathrm{N}_{2} \mathrm{O}$ losses in the housing unit and during manure storage. Methane emissions from enteric fermentations and manure are also estimated. A simulation example based on French technicoeconomic data illustrates how the model could be used to study the dynamics of animal populations within the system and of nutrient flows. Finally, there is a need for new knowledge (experimental data) to improve the model and help design more sustainable rabbit production systems by identifying best practices that minimise environmental impacts.
\end{abstract}

Additional keywords: ammonia, excretion, gas emission, greenhouse gas, manure.

Received 30 April 2014, accepted 13 July 2014, published online 15 October 2014

\section{Introduction}

In recent decades, livestock-farming practices have evolved considerably. To face the increasing demand for animal products throughout the world, small farms with traditional systems have been replaced by more intensive and confined farming systems with higher stocking densities. This intensification of livestock-farming systems has proven to be economically effective but is noted for its negative impact on the environment (FAO 2006) through the production of ammonia $\left(\mathrm{NH}_{3}\right)$ and greenhouse gases $(\mathrm{GHG})$ and a high usage of natural and non-renewable resources. Ammonia contributes to water pollution via eutrophication and soil pollution via acidification (Bouwman et al. 2002), whereas methane $\left(\mathrm{CH}_{4}\right)$ and nitrous oxide $\left(\mathrm{N}_{2} \mathrm{O}\right)$ are two major $\mathrm{GHG}$ responsible for global warming and likely climate change (IPCC 2007). In livestock systems, these gases are emitted mainly from manure in housing, in storage facilities or during spreading and grazing and are the main source of pollution of livestock-farming systems. Moreover, the misuse of manure (amounts, spreading dates) can also lead to pollutions such as nitrate leaching, phosphorus $(\mathrm{P})$ runoff or ecotoxicity due to heavy metal accumulation (FAO 2006).

Therefore, an accurate knowledge of the dynamics of nutrient flows in livestock-farming systems would help to design more sustainable systems regarding both their economic (e.g. improvement of feed conversion ratio) and environmental performances. In practice, nutrient flows in livestock systems can be evaluated through sampling and chemical analyses and using zootechnical data, but this approach is expensive, takes time and is difficult to carry out in commercial farms. A dynamic approach is also needed because pollutant leaks to groundwaters or the atmosphere can mainly be explained by a lack of synchronisation or an imbalance between their production 
(nitrates, $\mathrm{NH}_{3}, \mathrm{GHG}$ ) and their consumption or recycling into the agro-ecosystem. Furthermore, in order to prevent pollution swapping, studies should be comprehensive and developed at a large scale i.e. at the farm scale rather than at the animal scale (Rotz 2004; Monteny et al. 2006).

Concerning rabbit production, some studies dealing with the on-farm production of compounds with a potential impact on the environment can be found in the literature (Maertens et al. 2005; Calvet et al. 2008, 2011). They mostly dissociated nutrient excretion from gas emissions $\left(\mathrm{NH}_{3}, \mathrm{GHG}\right)$ whereas these two phases should be considered together to assess the proportion of nutrients lost to the atmosphere and therefore identify the best farming practices to reduce polluting gas emissions. Such a relation between farming practices and gas emissions has been previously shown using a life cycle assessment approach (Zened et al. 2013). In this study, the authors showed that global emissions of GHG and $\mathrm{NH}_{3}$ could be decreased by $\sim 10 \%$ in a rabbit farms when rabbits are submitted to a feed intake limitation during fattening rather than ad libitum feeding, due to a decrease in mortality, direct and indirect inputs use and manure production.

In such a context, modelling appears as a relevant tool to predict quickly and at a low cost the influence of farming practices (feed composition, reproduction and manure management) on nutrient flows at farm scale. Several models with such characteristics (sensitivity to practices, farm scale, dynamic and permitting a multi-criteria assessment) have been developed in the past but were mostly focussed on swine, dairy or poultry productions (Sise et al. 2011; Chardon et al. 2012; Méda et al. 2012; Rotz et al. 2012), and no model was found in the literature concerning rabbit production. Thus, the aim of this paper is to present a dynamic model able to predict the consequences of farming practices on nutrient [nitrogen $(\mathrm{N})$ and phosphorus $(\mathrm{P})]$ flows in rabbit farms.

\section{Model description}

The model runs on a daily time step and is composed of two submodels, the first one being dedicated to the simulation of animal populations and performance (mortality, growth, feed intake, milk production, fertility and prolificacy of does) and the second one to the simulation of nutrients flows (excretion, gas emissions). The nutrient flows taken into account in this submodel are represented in Fig. 1a. Input parameters (i.e. chosen by the user) and constants used in the model are described in Table 1.

The model describes a rabbit breeding-fattening farm composed of two identical housing units (1 and 2) in which the animals are managed under all-in/all-out principles. In such systems, does are transferred from one housing unit to the other at each weaning of young rabbits $\left(a g e_{\mathrm{W}}\right)$, whereas the fattened rabbits remain in the same unit from their birth until their slaughter $\left(a g e_{\mathrm{S}}\right)$. This system allows maintaining a depopulation period $\left[t_{\text {DepoP }}=\left(t_{\text {Cycle }}+a g e_{\mathrm{W}}\right)-a g e_{\mathrm{S}}\right]$ in each housing unit between the slaughter of rabbits and the next arrival of does (Fig. 1b).

\section{Animal performances submodel}

\section{Births, deaths and replacement of missing does}

In each stocking unit, the dynamics of three animal populations (does, replacement does and fatteners) are simulated using different equations (Eqns $1-8$ ) respectively for death + culling of does, replacement of does and birth and death of fatteners during maternity or fattening. The variation in the number of does $n_{\text {Does }}\left(t_{\text {After_Part }}\right)$ is calculated according to Eqn 1 according to time after the last parturition of does $\left(t_{\text {After_Part }}\right.$, $0 \leq t_{\text {After_Part }} \leq a g e_{\mathrm{W}}$ ) with two parameters: the maximal number of does in the farm ( $n_{\text {Does_max }}$ calculated from the average number of does on the farm $n_{\text {Does_av }}$, Eqn 2) and a mortality + culling rate per batch $\left(R_{\mathrm{M}+\text { C_Does }}, \%\right)$. At each weaning $\left(a g e_{\mathrm{W}}\right)$, the does are transferred to the other housing unit (Fig. 1b), and the missing does are replaced ( $n_{\text {Rdoes }}$, Eqn 3 ) at each artificial insemination so that the number of does is equal to $n_{\text {Does_max }} \cdot t_{\text {Cycle }}$ represents the duration of the reproduction cycle (time interval between two consecutive parturitions, day) and is calculated as the sum of the gestation duration (31 days) and the time interval between parturition and artificial insemination (input parameter, $t_{\text {Part_AI }}$, day).

$$
\begin{aligned}
& \text { If } t_{\text {After_Part }}=t_{\text {Part_AI }} \text {, then } n_{\text {Does }}=n_{\text {Does_max }} \text {, } \\
& \text { else } n_{\text {Does }}\left(t_{\text {After_Part }}\right)=n_{\text {Does }}\left(t_{\text {After_Part }}-1\right)-n_{\text {Does_max }} \\
& \times\left(R_{\mathrm{M}+\text { C_Does }} / t_{\text {cycle }}\right) \text {, } \\
& n_{\text {Does_max }}=n_{\text {Does_av }} /\left[1-\left(R_{\mathrm{M}+\mathrm{C} \_ \text {Does }} / 2\right)\right] \text { and } \\
& n_{\text {Rdoes }}=n_{\text {Does_max }} \times R_{\mathrm{M}+\mathrm{C} \_ \text {Does }} .
\end{aligned}
$$

For each parturition (every $t_{\text {Cycle }}$ time steps, Eqn 4 ), the number of live-born in the housing unit is calculated according to Eqn 5 using the number of does $n_{\text {Does }}$ and the following two input parameters: $R_{\text {Prolificacy_Does, }}$ the prolificacy of does (i.e. the number of newborn kept per doe after equalisation of litter size among does) and $R_{\text {Fertility_Does }}$, the fertility rate of does (i.e. the percentage of successful parturitions after artificial insemination, \%).

$$
\begin{gathered}
t_{\text {Cycle }}=31+t_{\text {Part_AI }}, \\
n_{\text {Tot_LB }}=n_{\text {Does }} \times R_{\text {Fertility_Does }} \times R_{\text {Prolificacy_Does }} .
\end{gathered}
$$

The number of rabbits (Eqn 6) in each fattening unit is then calculated using mortality rates per batch ( $R_{\mathrm{M} \_ \text {Fatt_Maternity }}$, $R_{\mathrm{M} \_ \text {Fatt_Fattening, }} \%$ ) for maternity and fattening periods (input parameters) respectively the age of the fatteners in each unit $\left(a g e_{\text {Fatt }}\right.$, day), the age at weaning and slaughter $\left(a g e_{\mathrm{W}}, a g e_{\mathrm{S}}\right.$, day) and the total number of live-born in the unit $n_{\text {Tot_LB }}$. To simplify our approach, we considered that the number of replacement does $\left(n_{\text {Rdoes }}\right)$ remains constant over time, i.e. not affected by mortality during nursing or fattening. The number of sucklings per lactating doe $\left(n_{\text {Litter }}\right)$ is calculated using Eqn 7 . The number of weaned rabbits (without considering $n_{\text {Rdoes }}$ ) per batch $\left(n_{\text {Tot_W }}\right)$ is calculated according to Eqn 8.

$$
\begin{aligned}
& \text { If } a g e_{\text {Fatt }}=0, \text { then } n_{\text {Fatt_Unit }}=n_{\text {Tot_LB }}+n_{\text {Rdoes }} . \\
& \text { If } a g e_{\text {Fatt }} \neq 0 \text { and } a g e_{\text {Fatt }} \leq a g e_{\mathrm{W}}, \text { then } n_{\text {Fatt_Unit }}\left(a g e_{\text {Fatt }}\right) \\
& =n_{\text {Fatt_Unit }}\left(a g e_{\text {Fatt }}-1\right)-\left[n_{\text {Tot_LB }}\right. \\
& \left.\times\left(R_{\mathrm{M} \_ \text {Fatt_Maternity }} / a g e_{\mathrm{W}}\right)\right]+n_{\text {Rdoes }} . \\
& \text { If } a g e_{\text {Fatt }}>a g e_{\mathrm{W}}, \text { then } n_{\text {Fatt_Unit }}\left(a g e_{\text {Fatt }}\right)=n_{\text {Rdoes }} \\
& \quad+n_{\text {Fatt_Unit }}\left(a g e_{\text {Fatt }}-1\right)-\left[n_{\text {Tot_W }}\right. \\
& \left.\quad \times\left(R_{\mathrm{M} \_ \text {Fatt_Fatteneing }} /\left(a g e_{\mathrm{S}}-a g e_{\mathrm{W}}\right)\right)\right],
\end{aligned}
$$


(a)

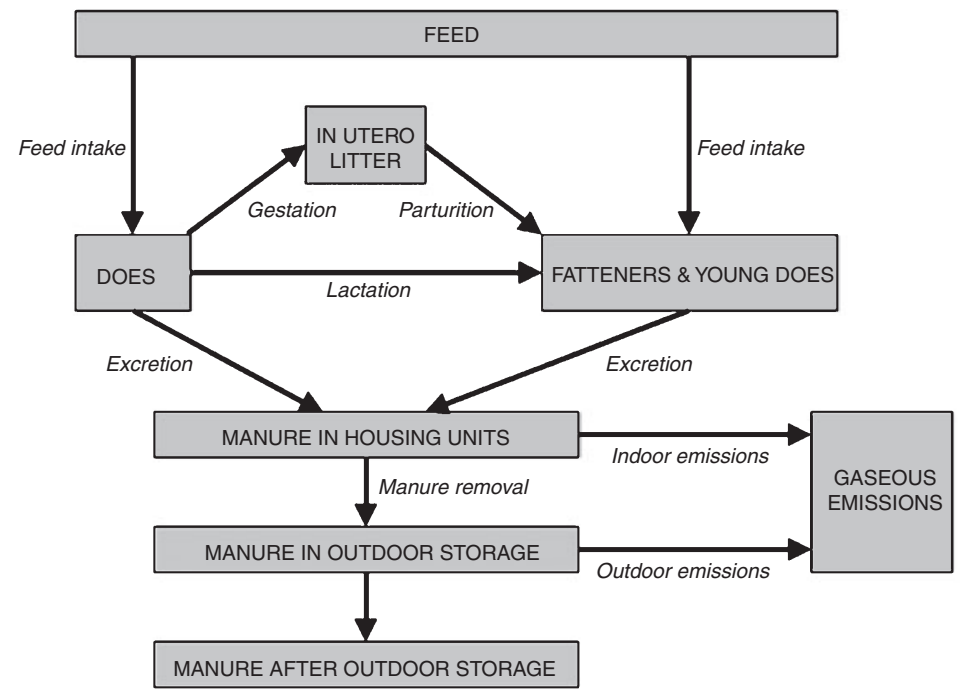

(b)

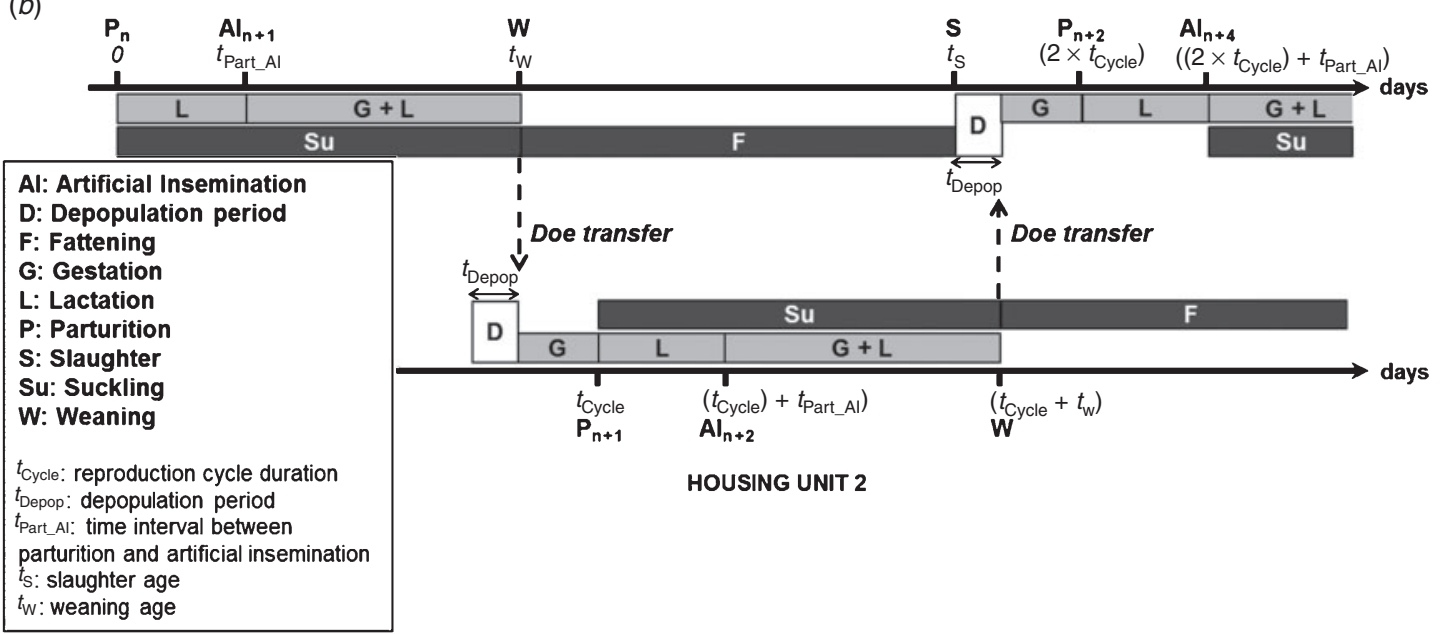

Fig. 1. General overview of the model. (a) Diagram representing the flows of nitrogen and phosphorus simulated in the model. (b) Schematic representation of an all-in/all-out rabbit production system simulated in the model according to reproduction management $\left(t_{\text {Cycle }}, t_{\text {Part_AI }}\right)$ and fattener management $\left(t_{\mathrm{W}}, t_{\mathrm{S}}\right)$.

$$
\begin{gathered}
n_{\text {Litter }}=n_{\text {Fatt_Unit }} /\left(n_{\text {Does }}\right), \\
n_{\text {Tot_W }}=n_{\text {Tot_LB }} \times\left(1-R_{\text {M_Fatt_Maternity }}\right) .
\end{gathered}
$$

Bodyweight, in utero litter growth, feed intake and milk production of the does

Several studies showed that during a reproduction cycle, doe bodyweight is subject to changes due to accretion and depletion of reserves (Feugier and Fortun-Lamothe 2006). However, the dynamics of these changes are difficult to represent in a modelling approach. Therefore, in our model, we considered that the empty bodyweight of the doe $\left(B W_{\text {Doe }}\right)$ is constant over time and that the in utero growth of the litter + fetal annexes $\left(D W G_{\text {Litter_in_utero }}\right)$ is the only change in the bodyweight of does. The growth of in utero litter + fetal annexes $\left(D W G_{\text {Litter_in_utero, }}, \mathrm{g} /\right.$ day.animal) is calculated using Eqn 9. To estimate the parameters of this equation, we assumed that at parturition, final weight of litter + fetal annexes is $\sim 125 \%$ of total weight of live-born kits and that at 24 days of gestation $\left(t_{\text {Gest }}=24\right)$, the litter + fetal annexes represented $\sim 20 \%$ of total weight of live-born kits $\left(n_{\text {Litter_atPart }} \times\right.$ $B W_{\mathrm{B}}$; Fortun et al. 1993):

$$
\begin{aligned}
& D W G_{\text {Litter_in_utero }}=a_{\text {fetal_growth }} \times \exp \left(a_{\text {fetal_growth }}\right. \\
& \left.\quad \times t_{\text {Gest }}+b_{\text {Fetal_growth }}\right)
\end{aligned}
$$

with $a_{\text {fetal_growth }}=\left[\ln \left(1.25 \times\left(n_{\text {Tot_LB }} / n_{\text {Does_max }}\right) \times B W_{\mathrm{B}}\right)\right.$

$$
\left.-\ln \left(0.2 \times\left(n_{\text {Tot_LB }} / n_{\text {Does_max }}\right) \times B W_{\mathrm{B}}\right)\right] /(31-24),
$$

$$
\begin{aligned}
& b_{\text {Fetal_growth }}=\ln \left[1.25 \times\left(n_{\text {Tot_LB }} / n_{\text {Does_max }}\right) \times B W_{\mathrm{B}}\right]-31 \\
& \quad \times a_{\text {fetal_growth. }}
\end{aligned}
$$

According to Maertens et al. (2006), milk production of does is influenced by many factors such as parity order, gestation overlapping degree, and genotype. The number of suckling kits is 
Table 1. Input parameters (user choice) used in the model. The values of input parameters were used to simulate a typical French rabbit farm (on the basis of technico-economic results of 2012)

Dml, dimensionless

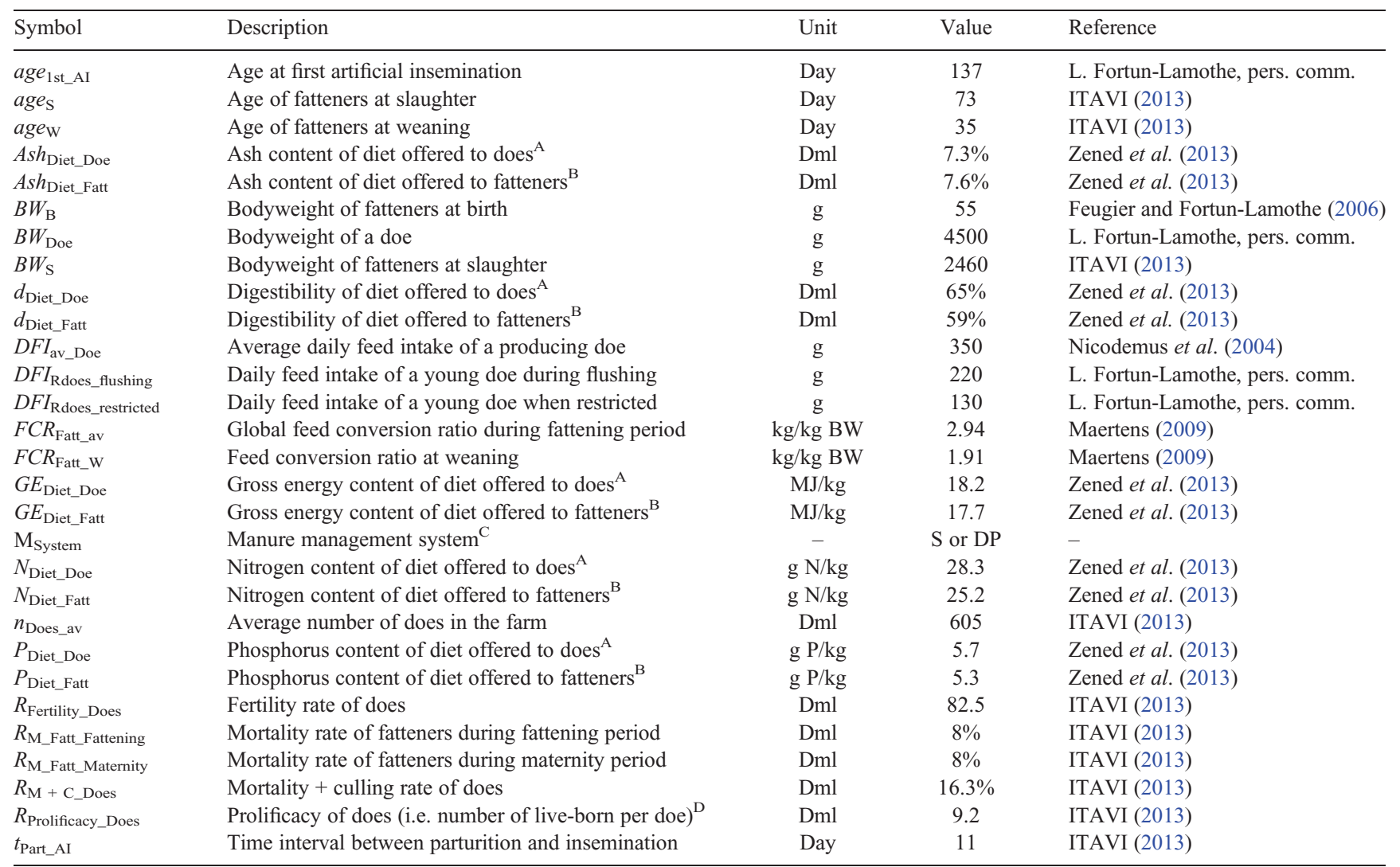

${ }^{\mathrm{A}}$ This diet is offered to does from parturition to 25 days after parturition, and from weaning to parturition. Therefore, it also offered to fatteners from birth to 25 days of age.

${ }^{\mathrm{B}}$ This diet is offered to fatteners from 25 days of age to slaughter. Therefore, it is also consumed by does between Day 25 after parturition and weaning of fatteners. ${ }^{\mathrm{C}} \mathrm{S}$, slurry; DP, deep-pit. Both manure management systems are simulated and discussed in the text.

${ }^{\mathrm{D}}$ Kept after equalisation of litter size among does.

also a factor affecting milk production and we used the equation of Maertens et al. (2006) to estimate the average milk production of does $\left(D M P_{\text {av }}, \mathrm{g} /\right.$ day.animal, Eqn 10). At each time step, the actual daily milk production $\left(D M P_{\text {Doe }}\right)$ can be calculated using Eqn 11, which simulates a lactation curve calibrated with $D M P_{\mathrm{av}}$, age $_{\mathrm{W}}$, and milk production at weaning $\left(D M P_{\mathrm{W}}, \mathrm{g} /\right.$ day.animal $)$ with a lactation peak occurring 19 days after parturition. $D M P_{\mathrm{W}}$ is calculated according to Eqn 12 using $t_{\text {Cycle }}$ (L. Fortun-Lamothe, pers. comm.).

$$
\begin{aligned}
& D M P_{\mathrm{av}}=37.47 \times n_{\text {Litter }}\left(t_{\text {After_Part }}=0\right) \\
& -1.56 \times n_{\text {Litter }}\left(t_{\text {After_Part }}=0\right)^{2} \text {. } \\
& \text { If } 19<t_{\text {After_Part }} \leq a g e_{\mathrm{W}} \text {, then } D M P_{\text {Doe }}=a_{2 \_ \text {DMP }} \\
& \times t_{\text {After_Part }}+b_{2 \_ \text {DMP }} \text {. } \\
& \text { If } t_{\text {After_Part }}>a g e_{\mathrm{W}} \text {, then } D M P_{\text {Doe }}=0 \text {, } \\
& \text { with } a_{1 \_\mathrm{DMP}}=a_{2 \_\mathrm{DMP}}+b_{2 \_\mathrm{DMP}} / 19 \text {, }
\end{aligned}
$$

$$
\begin{gathered}
a_{2 \_\mathrm{DMP}}=\left[2 \times\left(D M P_{\mathrm{av}} \times a g e_{\mathrm{W}}\right)-D M P_{\mathrm{W}} \times(2\right. \\
\left.\left.\times a g e_{\mathrm{W}}-19\right)\right] /\left[19 \times a g e_{\mathrm{W}}-a g e_{\mathrm{W}}{ }^{2}\right], \\
b_{2 \_\mathrm{DMP}}=D M P_{\mathrm{W}}-a_{2 \_\mathrm{DMP}} \times a g e_{\mathrm{W}}, \\
D M P_{\mathrm{W}}=2.19 \times t_{\text {Cycle }}+81.09 .
\end{gathered}
$$

Finally, daily feed intake of does ( $D F I_{\text {Doe }}, \mathrm{g} /$ day.animal) is calculated according to Eqn 13. This equation is calibrated using an average daily feed intake ( $\left.D F I_{\text {av_Doe }}\right)$ provided as a model input. We also assumed that $D F I_{\text {Doe }}$ is maximal 19 days after parturition (Maertens et al. 2006) and that does stop eating 2 days before parturition (L. Fortun-Lamothe, pers. comm.; Pascual et al. 2006):

$$
\begin{aligned}
& \text { if } t_{\text {After_Part }} \leq 19 \text {, then } D F I_{\text {Doe }}=a_{1 \_ \text {DFI_Doe }} \\
& \times t_{\text {After_Part }}+b_{1 \_ \text {DFI_Doe }} \text {. } \\
& \text { If } 19<t_{\text {After_Part }} \leq t_{\text {Cycle }}-3 \text {, then } D F I_{\text {Doe }}=a_{2 \_ \text {DFI_Doe }} \\
& \times t_{\text {After_Part }}+b_{2 \_D F I \_D o e} \text {. } \\
& \text { If } t_{\text {After_Part }}>t_{\text {Cycle }}-3 \text {, then } D F I_{\text {Doe }}=0 \text {, }
\end{aligned}
$$




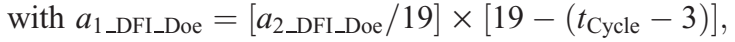

$$
\begin{aligned}
& a_{2 \_ \text {DFI_Doe }}=2 \times\left[\left(D F I_{\text {av_Doe }} \times\left(t_{\text {Cycle }}\right)\right)-(250\right. \\
& \left.\left.\times\left(t_{\text {Cycle }}-3\right)\right)\right] /\left[\left(t_{\text {Cycle }}-3\right) \times\left(19-\left(t_{\text {Cycle }}-3\right)\right)\right] \text {, } \\
& b_{1 \_ \text {DFI_Doe }}=250 \text {, } \\
& b_{2 \_ \text {DFI_Doe }}=250-a_{2 \text { _DFI_Doe }} \times\left(t_{\text {Cycle }}-3\right) \text {. }
\end{aligned}
$$

\section{Growth, milk and feed intakes of fatteners}

From birth to slaughter, the bodyweight of fatteners $\left(B W_{\text {Fatt }}, \mathrm{g}\right)$ is simulated using the Gompertz-modified function proposed by van Milgen et al. (2008) using age and bodyweight at birth $\left(0\right.$ days) and at slaughter $\left(a g e_{\mathrm{B}}, B W_{\mathrm{B}}, a g e_{\mathrm{S}}, B W_{\mathrm{S}}\right)$ and a precocity parameter $\left(B_{\mathrm{G}}\right)$ describing the shape of the growth curve (Eqn 14). The $B_{\mathrm{G}}$ was estimated to a value of 0.0314 by fitting the growth model on growth data provided by a rabbit genetic selection company. At each time step, the bodyweight gain of fatteners $\left(D B W G_{\text {Fatt }}, \mathrm{g} /\right.$ day) can be estimated according to Eqn 15:

$$
\begin{gathered}
B W_{\text {Fatt }}=B W_{\mathrm{S}} \times\left(B W_{\mathrm{S}} / B W_{\mathrm{B}}\right)^{\wedge}\left[-\left(\exp \left[-B_{\mathrm{G}} \times\left(a g e_{\mathrm{S}}-a g e_{\mathrm{B}}\right)\right]\right.\right. \\
\left.-\exp \left[-B_{\mathrm{G}} \times\left(a g e_{\text {Fatt }}-a g e_{\mathrm{B}}\right)\right]\right) /\left(-1+\exp \left[-B_{\mathrm{G}}\right.\right. \\
\left.\left.\left.\times\left(a g e_{\mathrm{S}}-a g e_{\mathrm{B}}\right)\right]\right)\right], \\
\quad D B W G_{\text {Fatt }}=\mathrm{d} B W_{\text {Fatt }} / \mathrm{d} A g e_{\text {Fatt }} .
\end{gathered}
$$

Before weaning, the daily milk intake $\left(D M I_{\text {Fatt }}\right)$ of fatteners is calculated as the ratio between milk production per $\operatorname{doe}\left(D M P_{\text {Doe }}\right)$ and litter size $\left(n_{\text {Litter }}\right)$ according to Eqn 16 . It has also been observed that after 17 days of age, fatteners start to consume solid feed offered to the doe. Therefore, using the data published by Orengo and Gidenne (2007), a linear model was fitted to predict the feed intake of the fattener $\left(D F I_{\text {Fatt }}\right)$ between birth and weaning (Eqn 17). After weaning, we considered that $D F I_{\text {Fatt }}$ is equal to the product of $D B W G_{\text {Fatt }}$ by the feed conversion ratio of the fattening period $\left(F C R_{\text {Fatt }}\right)$. According to Maertens (2009), $F C R_{\text {Fatt }}$ increases linearly from weaning to slaughter, therefore we considered such an evolution in Eqn 18 using an average $F C R$ for the whole fattening period $\left(F C R_{\text {Fatt_av }}\right)$ and a $F C R$ value at weaning $\left(F C R_{\text {Fatt_W }}\right)$ as input parameters (Table 1$)$.

$$
\begin{aligned}
& \text { If } a g e_{\text {Fatt }} \leq a g e_{\mathrm{W}} \text {, then } D M I_{\text {Fatt }}=D M P_{\text {Doe }} / n_{\text {Litter }}, \\
& \text { else } D M I_{\text {Fatt }}=0 . \\
& \quad \text { If } a g e_{\text {Fatt }} \leq 17 \text {, then } D F I_{\text {Fatt }}=0 . \\
& \text { If } a g e_{\text {Fatt }}>17 \text { and } a g e_{\mathrm{t}}>a g e_{\mathrm{W}} \text {, then } D F I_{\text {Fatt }}=2.81 \\
& \times \text { age }_{\text {Fatt }}-50.06 \text {. }
\end{aligned}
$$

If $a g e_{\text {Fatt }} \geq a g e_{\mathrm{W}}$, then $D F I_{\text {Fatt }}=F C R_{\text {Fatt }} \times D B W G_{\text {Fatt }}$,

$$
F C R_{\text {Fatt }}=a_{\text {FCR_Fatt }} \times a g e_{\text {Fatt }}+b_{\text {FCR_Fatt }},
$$

with $a_{\mathrm{FCR} \_ \text {Fatt }}=\left(F C R_{\text {Fatt_S }}-F C R_{\text {Fatt_W }}\right) /\left(a g e_{\mathrm{S}}-a g e_{\mathrm{W}}\right)$,

$$
b_{\mathrm{FCR} \_ \text {Fatt }}=F C R_{\text {Fatt_W }}-a F C R_{\text {_Fatt }} \times a g e_{\mathrm{W}},
$$

$F C R_{\text {Fatt_S }}=2 \times F C R_{\text {Fatt_av }}-F C R_{\text {Fatt_W }}\left(F C R_{\text {Fatt_S }}\right.$ : FCR at slaughter $)$.

\section{Rearing of replacement does}

At each batch, replacement does represent $\sim 15-20 \%$ of the total number of does (Maertens et al. 2005). In our model, we considered that these young does are bought and arrive at 1 day of age in the farm. They are adopted by lactating does and are reared as fatteners born on the farm up to slaughtering age (growth and feed intake described using Eqns 14-18). Between slaughtering age and first insemination (age 1st_AI $_{1}$ ), replacement does continue to grow (up to $B W_{\text {Doe }}$ ) with a constant daily gain $D W G_{\text {Rdoes }}$ (Eqn 19) Moreover until first parturition (i.e. at $a g e_{1 s t \_A I}+$ 31 days), replacement does are mostly feed restricted (except around first AI i.e. flushing). In our model, we therefore considered feed intake during preparation $\left(D F I_{\text {Rdoes }}\right)$ using Eqn 20 with $D F I_{\text {Rdoes_restricted }}$ and $D F I_{\text {Rdoes_flushing }}$ daily feed intakes during feed restriction or flushing ( $\mathrm{g} /$ day.animal) whereas after parturition Eqn 13 for DFI was used.

$$
D W G_{\mathrm{Rdoes}}=\left[\left(B W_{\text {Doe }}-B W_{\mathrm{S}}\right) /\left(a g e_{1 \mathrm{st} \_\mathrm{AI}}-a g e_{\mathrm{S}}\right)\right] .
$$

If $a g e_{\text {Rdoes }}<\left(a g e_{1 \mathrm{st} \_\mathrm{AI}}-7\right)$ or $a g e_{\mathrm{Rdoes}}>\left(\operatorname{ag} e_{1 \mathrm{st} \_\mathrm{AI}}+4\right)$,

then $D F I_{\text {Rdoes }}=D F I_{\text {Rdoes_restricted }}$.

If $a g e_{\text {Rdoes }} \geq\left(a g e_{1 \mathrm{st} \_\mathrm{AI}}-7\right)$ and $a g e_{\mathrm{Rdoes}} \leq\left(a g e_{1 \mathrm{st} \_\mathrm{AI}}+4\right)$,

then $D F I_{\text {Rdoes }}=D F I_{\text {Rdoes_flushing. }}$.

\section{Manure and gaseous emissions submodel}

\section{Nutrient excretion}

For females, at each time step, we assumed that empty bodyweight of does is constant over time (i.e. no variation in body reserves). Therefore, the excretion of the nutrient $X$ per doe ( $X_{\text {Excretion_Doe, }} \mathrm{g} /$ day.animal) with $\mathrm{X}$ being either $\mathrm{N}$ or $\mathrm{P}$, can be calculated as the difference between daily feed intake $\left(D F I_{\text {Doe }}\right)$ and daily milk production $\left(D M P_{\text {Doe }}\right)$ and daily weight gain of in utero litter ( $\left.D W G_{\text {Litter_in_utero }}\right)$ according to Eqn 21 . When does stop eating just before parturition, we considered that excretions of $\mathrm{N}$ and $\mathrm{P}$ were respectively $5 \mathrm{~g} \mathrm{~N} /$ day and $1 \mathrm{~g} \mathrm{P} /$ day (extrapolation of excretion rates simulated by our model just before does stop eating). For replacement does, Eqn 22 is used during their preparation (i.e. before $a g e_{1 s t \_A I}$ ). For nonlactating does (first gestation or failed AI), Eqn 21 is used but milk production is not taken into account $\left(D M P_{\mathrm{Doe}}=0\right)$. For fatteners, the $\times$ excretion per fattener $\left(X_{\text {Excretion_Fatt, }} \mathrm{g} /\right.$ day.animal $)$ is calculated as the difference between intake (milk, $D M I_{\text {Fatt }}$; feed, $\left.D F I_{\text {Fatt }}\right)$ and body retention $\left(D W G_{\text {Fatt }}\right)$ according to Eqn 23. Values of milk composition were respectively of $19.7 \mathrm{~g} \mathrm{~N} / \mathrm{kg}$ and $2.4 \mathrm{~g} \mathrm{P} / \mathrm{kg}$ (Maertens et al. 2006). Body composition (in utero litter, bodyweight) was considered to be constant with values of $29 \mathrm{~g} \mathrm{~N} / \mathrm{kg}$ and $5 \mathrm{~g} \mathrm{P} / \mathrm{kg}$ respectively (Maertens et al. 2005).

$$
\begin{aligned}
& \text { If } D F I_{\text {Doe }} \neq 0, \text { then } X_{\text {Excretion_Doe }}=D F I_{\text {Doe }} \times X_{\text {Diet_Doe }} \\
& -D M P_{\text {Doe }} \times X_{\text {Milk }}-D W G_{\text {Litter_in_utero }} \times X_{\text {Litter }}, \\
& \text { else } N_{\text {Excretion_Doe }}=5 \text { AND } P_{\text {Excretion_Doe }}=1 . \\
& X_{\text {Excretion_Rdoes }}=D F I_{\text {Rdoes }} \times X_{\text {Diet_Rdoes }}-D W G_{\text {Rdoes }} \\
& \times X_{\text {Body_Rdoes }}, \\
& X_{\text {Excretion_Fatt }}=D F I_{\text {Fatt }} \times X_{\text {Diet_Fatt }}+D M I_{\text {Fatt }} \times X_{\text {Milk }} \\
& -D W G_{\text {Fatt }} \times X_{\text {Body_Fatt }} .
\end{aligned}
$$

Daily total excretion of $\mathrm{X}(\mathrm{g} /$ day) of animals in each category (does, replacement does and fatteners) at the farm scale are then 
calculated by multiplying individual excretion by the total number of animal of each category (Eqns 24-26). Total excretion over time at the farm scale of X ( $X_{\text {Total_Excretion_Farm, }}$ g) is calculated according to Eqn 27.

$$
\begin{gathered}
X_{\text {Total_Excretion_Does }}=X_{\text {Excretion_Doe }} \times n_{\text {Does }}, \\
X_{\text {Total_Excretion_Rdoes }}=X_{\text {Excretion_Rdoe }} \times n_{\text {Rdoes }}, \\
X_{\text {Total_Excretion_Fatt }}=\left(X_{\text {Excretion_Fatt }} \times n_{\text {Fatt }}\right)_{\text {Housing_Unit1 }} \\
+\left(X_{\text {Excretion_Fatt }} \times n_{\text {Fatt }}\right)_{\text {Housing_Unit2 }}, \\
X_{\text {Total_Excretion_Farm }}=\int\left(X_{\text {Total_Excretion_Does }}\right. \\
\left.+X_{\text {Total_Excretion_Rdoes }}+X_{\text {Total_Excretion_Fatt }}\right) .
\end{gathered}
$$

\section{Gaseous N losses}

In rabbit farms, manure can be managed as slurry (daily removed from the housing units before being stored for several months outdoors, called S hereafter) or as solid manure (accumulated in deep pits below animals for several months before being removed once or twice a year, called DP hereafter). With our model, it is possible to simulate both manure management systems (input parameter $\mathrm{M}_{\text {System, }}$ Table 1). However, very few data concerning gas emissions from rabbit manure are available in the literature to calibrate our model. Therefore, data for slurry management were taken from pig references.

According to the EMEP/EEA methodology (EEA 2013), gaseous $\mathrm{N}$ emissions from manure originate from total ammoniacal $\mathrm{N}$ excreted $\left(T A N_{\mathrm{ex}}\right)$, which represents $60 \%$ of total $\mathrm{N}$ excreted (TAN content_ex $_{\text {) }}$ in S or DP systems (Eqn 28). Among the $\mathrm{N}$-compounds emitted in the housing units, $\mathrm{NH}_{3}$ is the most important and represent $\sim 25$ of TAN excreted $\left(E F_{\mathrm{NH} 3 \text { _Housing }}\right)$ by the animals in $\mathrm{S}$ or $\mathrm{DP}$ systems respectively (EEA 2013). However, a daily removal of slurry from housing units is known to greatly decrease $\mathrm{N}$ losses $(\sim 35 \%)$ according to Rigolot et al. (2010). Therefore, we considered that in the S system, $E F_{\mathrm{NH} 3 \_ \text {Housing }}$ represents only $65 \%$ of the default emission factors of $25 \%$ (i.e. $E F_{\mathrm{NH} 3 \_ \text {Housing }}=16.25 \%$ ). $\mathrm{NH}_{3}-\mathrm{N}$ emissions in housing units are then estimated using the EMEP/EEA methodology (EEA 2013) and converted into $\mathrm{NH}_{3}$ emissions $\left(E_{\mathrm{NH} 3}\right.$ Housing, $\left.\mathrm{g} \mathrm{NH}_{3}\right)$ by multiplying this value by a 17/14 factor (Eqn 29). Total losses of $\mathrm{N}$ through gas emissions in the housing units ( $\left.E_{\mathrm{N} \_ \text {Losses_ Housing, }} \mathrm{g} \mathrm{N}\right)$ were assumed to represent, in both manure management systems, 30\% ( $\left.E F_{\text {Ntot_Housing }}\right)$ of excreted TAN as the emission of $\mathrm{N}$ compounds other than $\mathrm{NH}_{3}\left(\mathrm{~N}_{2} \mathrm{O}, \mathrm{NO}, \mathrm{N}_{2}\right)$ is very limited in rabbit manure (M. Hassouna, pers. comm.; Rigolot et al. 2010). For the $\mathrm{S}$ system, this default emission factor was also weighted by a $65 \%$ factor to take into account the daily removal of slurry (Rigolot et al. 2010). Total $\mathrm{N}$ gaseous losses in housing units are

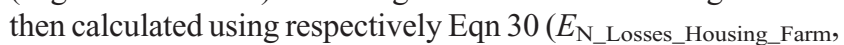
g N).

$$
\begin{aligned}
& T A N_{\text {ex }}=N_{\text {Total_Excretion_Farm }} \times T A N_{\text {content_ex }}, \\
& E_{\mathrm{NH} 3 \_ \text {Housing }}=T A N_{\mathrm{ex}} \times E F_{\mathrm{NH} 3 \_ \text {Housing }} \times(17 / 14) \text {, } \\
& E_{\mathrm{N} \_ \text {Losses_Housing_Farm }}=T A N_{\mathrm{ex}} \times E F_{\text {Ntot_Housing }} .
\end{aligned}
$$

TAN in manure entering storage $\left(T A N_{\text {stored }}\right)$ can be calculated using Eqn 31, assuming that in the $\mathrm{S}$ system 10\% of nonammoniacal $\mathrm{N}$ has been transformed into ammoniacal $\mathrm{N}$ before entering storage and that, in the DP system, $0.67 \%$ of remaining TAN is immobilised in organic matter (EEA 2013). Data concerning the storage of rabbit manure according to manure management system are scarce. Therefore, we considered that emissions of $\mathrm{NH}_{3}$ during storage $\left(E_{\mathrm{NH} 3 \text { _Storage_Farm, }} \mathrm{g} \mathrm{NH}_{3}\right)$ are the same in both $\mathrm{S}$ and DP systems. They are calculated using Eqn 32 assuming that $14 \%\left(E F_{\mathrm{NH} 3 \text { _Storage }}\right)$ of $T A N_{\text {stored }}$ are lost (EEA

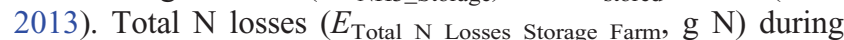
storage are calculated using Eqn 33 assuming that 14.31\% (EEA 2013) of $T A N_{\text {stored }}$ is lost in both manure management systems.

$$
\begin{aligned}
& T A N_{\text {stored }}=\left(T A N \text { ex }-E_{\mathrm{N} \_ \text {Losses_Housing_Farm }}\right)+0.1 \\
& \times\left[N_{\text {Total_Excretion_Farm }}-\left(T A N \text { ex }-E_{\text {N_Losses_Housing_Farm }}\right)\right] \\
& \text { for slurry systems, } \\
& T A N_{\text {stored }}=\left(T A N \text { ex }-E_{\text {N_Losses_Housing_Farm }}\right) \\
& \times(1-0.0067) \text { for deep-pit systems, } \\
& E_{\mathrm{NH} 3 \text { _Storage_Farm }}=T A N_{\text {stored }} \times E F_{\mathrm{NH} 3 \text { _Storage }} \times(17 / 14) \text {, } \\
& E_{\text {Total_N_Losses_Storage_Farm }}=T A N_{\text {stored }} \times E F_{\text {Ntot_Storage }} .
\end{aligned}
$$

For $\mathrm{N}_{2} \mathrm{O}-\mathrm{N}$ emissions, we considered the Tier 2 approach proposed by the IPCC (2006). A global emission factor ( $E F_{\text {N2O_Farm }}$ ) is used to evaluate $\mathrm{N}_{2} \mathrm{O}$ emissions in housing units and during outdoor storage. This value is $0 \%$ in the $\mathrm{S}$ system and $0.2 \%$ of $N_{\text {Total_Excretion_Farm }}$ in the DP system. $\mathrm{N}_{2} \mathrm{O}-\mathrm{N}$ emissions are converted into $\mathrm{N}_{2} \mathrm{O}\left(E_{\mathrm{N} 2 \mathrm{O} \text { Farm }}, \mathrm{g} \mathrm{N}_{2} \mathrm{O} /\right.$ day $)$ using a 44/28 factor (Eqn 34):

$E_{\text {N2O_Farm }}=N_{\text {Total_Excretion_Farm }} \times E F_{\text {N2O_Farm }} \times(44 / 28)$.

\section{Final nutrient amounts in manure after storage}

The final amount of $\mathrm{N}$ in manure after storage $\left(N_{\text {inManure }}\right.$ After_Storage_Farm) is calculated with Eqn 35 as the difference between amount total $\mathrm{N}$ excreted and total $\mathrm{N}$ losses in housing units and during storage. For $\mathrm{P}$, as it is non-volatile, the final amount was assumed to be the same as total excretion (Eqn 36), even though this amount may be lower when manure is spread due to the sedimentation of P in the storage pit (Levasseur et al. 2007).

$$
\begin{aligned}
& N_{\text {inManure_After_Storage_Farm }}=N_{\text {Total_Excretion_Farm }} \\
& -\left(E_{\text {Total_N_Losses_Housing_Farm }}+E_{\text {Total_N_Losses_Storage_Farm }}\right), \\
& P_{\text {inManure_After_Storage_Farm }}=P_{\text {Total_Excretion_Farm }}
\end{aligned}
$$

\section{Enteric and manure $\mathrm{CH}_{4}$ emissions}

Data from in vivo and in vitro studies showed that in rabbit species enteric $\mathrm{CH}_{4}$ production is much lower than in ruminant herbivorous such as the cow and is highly variable between individuals. Those studies also showed a strong effect of diet composition (e.g. fibre and starch contents) and of age with essentially no emissions for young rabbits (Piattoni et al. 1996; Marounek et al. 1999; Belenguer et al. 2011; Franz et al. 2011). Therefore, in this model, we considered that $\mathrm{CH}_{4}$ enteric emissions were negligible before weaning and that after 
weaning they represent $\sim 0.4 \%$ of gross energy intake (GEI, MJ/ day). Enteric emissions ( $E_{\mathrm{CH} 4 \_ \text {Enteric }}, \mathrm{g} \mathrm{CH}_{4} /$ day) were then calculated using IPCC approach (2006) (Eqn 36) with 55.65, the energy content of $\mathrm{CH}_{4}(\mathrm{MJ} / \mathrm{kg} \mathrm{CH})$ and GEI calculated according to Eqn 37 from gross energy content of diet ( $G E_{\text {Diet }}$, $\mathrm{MJ} / \mathrm{kg}$ ) and daily feed intake (DFI):

$$
\begin{gathered}
E_{\mathrm{CH} 4 \_ \text {Enteric }}=1000 \times \mathrm{GEI} / 55.65, \\
\mathrm{GEI}=G E_{\text {Diet }} \times(\mathrm{DFI} / 1000) .
\end{gathered}
$$

Concerning total daily $\mathrm{CH}_{4}$ emissions from manure, the Tier 2 approach proposed by the IPCC (2006) was used. For each animal category (does, replacement does and fatteners), excretion of manure volatile solids (VS, $\mathrm{kg} /$ day.animal) at the origin of $\mathrm{CH}_{4}$ emissions is estimated using Eqn 38 with $d_{\text {Diet }}$ being the diet digestibility (\%),the urinary energy (UE) considered to represent $3 \%$ of GEI (Xiccato and Trocino 2010), the ash content of the diet $\left(A s h_{\text {Diet }}\right)$ and 18.45 the conversion factor for dietary GE per $\mathrm{kg}$ of dry matter. Indoor and outdoor $\mathrm{CH}_{4}$ manure emissions ( $E_{\mathrm{CH} 4 \_ \text {Manure, }} \mathrm{g} \mathrm{CH}_{4} /$ day.animal) are estimated for each animal category respectively with Eqn 39 with $\mathrm{B}_{0}$ being the maximum $\mathrm{CH}_{4}$ producing capacity $\left[0.058 \mathrm{~m}^{3} \mathrm{CH}_{4} / \mathrm{kg}\right.$ VS according to Ferrer et al. (2011)], 0.67 the conversion factor of $\mathrm{m}^{3} \mathrm{CH}_{4}$ to $\mathrm{kg} \mathrm{CH}$ and $M C F_{\text {Manure }}$ the respective $\mathrm{CH}_{4}$ conversion factor.

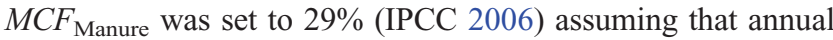
outdoor average temperature is below $16^{\circ} \mathrm{C}$ and can be applied for the two manure management systems described earlier (S or DP).

$$
\begin{aligned}
\mathrm{VS}= & {\left[\mathrm{GEI} \times\left(1-d_{\text {Diet }}\right)+(\mathrm{UE} \times \mathrm{GEI})\right] } \\
& \times\left[\left(1-A s h_{\text {Diet }}\right) / 18.45\right], \\
E_{\mathrm{CH} 4 \_ \text {Manure }}= & \mathrm{VS} \times B_{0} \times 0.67 \times M C F_{\text {Manure }} / 1000 .
\end{aligned}
$$

\section{Simulation of a typical French rabbit farm with a reproduction cycle of $\mathbf{4 2}$ days according to manure management systems}

In this section, we present and discuss the results obtained from the run of the model applied to a theoretical typical French rabbit farm: 605 does and 42 days reproduction rhythm (ITAVI 2013) for two different manure management systems ( $\mathrm{S}$ or DP). Average annual results were calculated from 5-year simulation runs. Data and references used for the parameterisation of the simulations are given in Table 1.

\section{Nutrient intake, excretion and final amount in manure}

Nitrogen and $\mathrm{P}$ intake are given in Table 2 . At the farm scale, $\sim 8 \mathrm{t}$ and $1.6 \mathrm{t}$ of $\mathrm{N}$ and $\mathrm{P}$ were consumed by animals (feed) of which $70 \%$ have been consumed by fatteners. Total excretion at farm scale of $\mathrm{N}$ and $\mathrm{P}$ represent respectively $\sim 61 \%$ and $68 \%$ of total intake. For fatteners, excretion represents a much higher percentage of intake than for does (respectively 68\% vs 47\%). In our simulation, excretion of $\mathrm{N}$ and $\mathrm{P}$ per doe differs from values proposed by Maertens et al. (2005) but is consistent with the French steering committee for environmental-friendly farming practices (CORPEN 1999) (8.2 vs 7.4 vs $8.1 \mathrm{~kg} \mathrm{~N}$ and $1.8 \mathrm{vs} 2.1 \mathrm{vs}$ $1.9 \mathrm{~kg} \mathrm{P}$ respectively). Differences in $\mathrm{N}$ and $\mathrm{P}$ excretion values between our study and that of Maertens et al. (2005) can be explained by a higher $\mathrm{N}$ intake in our study $(13.2 \mathrm{vs} 11.0 \mathrm{~kg} \mathrm{~N})$ and a higher $\mathrm{P}$ body deposition $(0.9$ and $0.6 \mathrm{~kg} \mathrm{P})$ for a similar intake $(2.7 \mathrm{~kg} \mathrm{P})$. In our study, $\mathrm{N}$ excretion per $\mathrm{kg}$ produced $(53.9 \mathrm{~g})$ is $\sim 30 \%$ higher than the value of $41.3 \mathrm{~g} \mathrm{~N}$ per $\mathrm{kg}$ produced proposed by Calvet et al. (2008). That might be explained by the difference in slaughter weight in both studies ( 2.46 and $1.8 \mathrm{~kg} \mathrm{BW}$ ) because feed efficiency decreases in heavier animals (higher excretion rate).

After storage, the remaining $\mathrm{N}$ in manure represents $50 \%$ and $47 \%$ of total $\mathrm{N}$ intake in the farm in the $\mathrm{S}$ and DP systems respectively (Table 2). The value for the DP system is inconsistent with the value proposed by CORPEN $(27 \% ; 1999)$. However, this can be explained by the lower proportion of total N excreted that is lost in housing and during storage in our model (24\% vs $60 \%)$. Concerning $\mathrm{P}$, our results show a small decrease in the ratio $\mathrm{P}$ in manure after storage/P intake between our model output data (Table 2) and CORPEN (1999) data (68\% vs 71\% respectively), which can be related to the improvement of feed efficiency of animals between CORPEN study (1999) and ours.

\begin{tabular}{|c|c|c|c|c|c|c|}
\hline & $\begin{array}{c}\text { Total does } \\
\text { (kg/year) }\end{array}$ & $\begin{array}{c}\text { Total fatteners } \\
\text { (kg/year) }\end{array}$ & $\begin{array}{c}\text { Total farm } \\
\text { (kg/year) }\end{array}$ & $\begin{array}{l}\text { Per produced } \\
\text { fattener }(\mathrm{g})\end{array}$ & $\begin{array}{l}\text { Per doe } \\
\quad(\mathrm{g})\end{array}$ & $\begin{array}{r}\text { Rabbit meat } \\
(\mathrm{g} / \mathrm{kg} \mathrm{LW})\end{array}$ \\
\hline \multicolumn{7}{|c|}{ Nitrogen } \\
\hline Intake & 2438 & 5562 & 8000 & 215.9 & 13.2 & 87.4 \\
\hline Excretion & 1147 & 3787 & 4934 & 133.1 & 8.2 & 53.9 \\
\hline \multicolumn{7}{|c|}{ In manure after storage } \\
\hline Slurry system & 925 & 3054 & 3979 & 107.4 & 6.6 & 43.5 \\
\hline Deep-pit system & 872 & 2879 & 3751 & 101.2 & 6.2 & 41.0 \\
\hline \multicolumn{7}{|c|}{ Phosphorus } \\
\hline Intake & 493 & 1120 & 1613 & 43.5 & 2.7 & 17.6 \\
\hline Excretion & 332 & 767 & 1100 & 29.7 & 1.8 & 12.0 \\
\hline \multicolumn{7}{|c|}{ In manure after storage } \\
\hline Slurry system & 332 & 767 & 1100 & 29.7 & 1.8 & 12.0 \\
\hline Deep-pit system & 332 & 767 & 1100 & 29.7 & 1.8 & 12.0 \\
\hline
\end{tabular}

Table 2. Performances of a typical French rabbit farm of 605 does for nitrogen $(\mathrm{N})$ and phosphorus (P) intake, excretion and final amount in manure after storage according to manure management system (slurry or deep-pit)

LW, liveweight. Total does include rearing of replacement does. Values per doe are total farm amount divided by the average number of does on farm ( $\left.\mathrm{n}_{\text {Does_av }}=605\right)$. Rabbit meat includes also the meat from $2 / 3$ of culled does (see Maertens et al. 2005) 


\section{Gaseous emissions}

Table 3 summarises annual gaseous emissions of $\mathrm{CH}_{4}, \mathrm{NH}_{3}$ and $\mathrm{N}_{2} \mathrm{O}$ of the simulated farm. Ammonia is the first compound emitted with 1030 and $1248 \mathrm{~kg}$ per year for the S and DP systems respectively. Even though the order of magnitude of total emissions is similar, the partition between housing and storage emissions is different in the $\mathrm{S}$ and DP systems. Ammonia emissions from housing units represent indeed $\sim 72 \%$ of total farm emissions in the DP system whereas they represent only $57 \%$ in the $\mathrm{S}$ system. Moreover, $\mathrm{NH}_{3}$ emissions due to excretion of fatteners are the main source of $\mathrm{NH}_{3}$ with $\sim 77 \%$ of total farm emissions in relation with the larger contribution of fatteners to $\mathrm{N}$ excretion. Concerning $\mathrm{N}_{2} \mathrm{O}$, because the emission factor is $0 \%$ in the $\mathrm{S}$ system, emissions are observed only in the DP system and represent $16 \mathrm{~kg}$ per year with a similar repartition between fatteners and does as for $\mathrm{NH}_{3}$ (77\% vs 23\%). Thus, the S system with a daily removal appears to be a more efficient manure management system for rabbit manure to decrease the emissions of $\mathrm{NH}_{3}$ and $\mathrm{N}_{2} \mathrm{O}$. This is in agreement with the IPPC BREF document (European Commission 2003), which considers that removing manure frequently is a best available technique in pig or laying hen housings. Furthermore, a reduction of indoor $\mathrm{NH}_{3}$ emissions is also beneficial regarding animal and farmer welfare (decrease of respiratory diseases) as reported by Kristensen and Wathes (2000) and Whyte (1993) respectively.

Concerning $\mathrm{CH}_{4}$ emissions, total farm emissions are the same in both manure management systems $(1626 \mathrm{~kg})$ in relation to the identical emission factors used in both simulations. Manure is the main source of $\mathrm{CH}_{4}$ with $\sim 73 \%$ of total emissions in comparison with enteric fermentation (27\%). Fatteners are the largest producers of $\mathrm{CH}_{4}$ with $\sim 70 \%$ of total emissions (Table 3 ).

Very few experimental references concerning gas emissions from rabbit farms are available in the literature. Calvet et al. (2011) proposed respective values for maternity and fattening units with the DP manure management system. Our $\mathrm{NH}_{3}$ values are higher than those of Calvet et al. (2011) (1.93 vs $1.34 \mathrm{~g} \mathrm{NH}_{3} /$ doe.day and 0.22 vs $0.24 \mathrm{~g} \mathrm{NH}_{3}$ /fattener.day respectively) but in our approach we also considered storage emissions. When considering only indoor emissions, values are much closer respectively with 0.22 vs $0.24 \mathrm{~g} \mathrm{NH}_{3}$ /fattener.day and $1.39 \mathrm{vs}$ $1.34 \mathrm{~g} \mathrm{NH}_{3}$ /doe.day respectively. The $\mathrm{N}_{2} \mathrm{O}$ emissions for does + litter are more than 10 times higher in Calvet et al. (2011) than in our study ( 0.247 vs $0.03 \mathrm{~g} \mathrm{~N}_{2} \mathrm{O} /$ doe.day respectively) whereas during fattening emissions are very low in both studies $(<5 \mathrm{mg}$ per day per animal). Our value should have been higher than the value proposed by Calvet et al. (2011) as it also includes storage emissions. However, it is difficult to explain this difference of does + litter emissions between both studies because there are large uncertainties both on emissions factors from the literature (Méda et al. 2011) and on the measurement technique used in the experimental study of Calvet et al. (2011). Issues of over- and underestimation of emissions (due to interferences between gases) have indeed been reported in the literature (Hassouna et al. 2013) when they are measured using infrared spectrometry.

In our model, we used reference methodologies for the estimation of emissions from livestock (IPCC 2006; EEA 2013) and we tried to take into account the influence of manure management on these emissions by considering specific emissions factors for the two major manure management systems in rabbit (S or DP). However, our approach was limited by the lack of data specifically dedicated to rabbit farms. For instance, in the S system, pig slurry references were used for $\mathrm{NH}_{3}$ emission factors and for storage emissions, so we assumed that $\mathrm{NH}_{3}$ and total $\mathrm{N}$ emissions factors were the same in both systems. Even though specific emission factors are always associated with uncertainties, the acquisition of specific emission factors for rabbit farms according to manure management system is required. These experiments should be based on referenced and reliable measuring techniques such as mass balances, infrared spectrometry and gas chromatography. This will be the most efficient way to improve and develop modelling approaches such ours and therefore decrease uncertainties in these models and in national inventories based on these models (Méda et al. 2011).

Table 3. Emissions of ammonia $\left(\mathrm{NH}_{3}\right)$, nitrous oxide $\left(\mathrm{N}_{2} \mathrm{O}\right)$ and methane $\left(\mathrm{CH}_{4}\right)$ from a typical French rabbit farm of 605 does

LW, liveweight. Values for total does and total fatteners include storage emissions. Values for does + litter emissions include emissions from growing rabbits before weaning and emissions associated to the rearing of replacement does. Rabbit meat also includes the meat from $2 / 3$ of culled does (see Maertens et al. 2005)

\begin{tabular}{|c|c|c|c|c|c|c|}
\hline & $\begin{array}{c}\text { Total does } \\
\text { (kg/year) }\end{array}$ & $\begin{array}{l}\text { Total fatteners } \\
\text { (kg/year) }\end{array}$ & $\begin{array}{c}\text { Total farm } \\
\text { (kg/year) }\end{array}$ & $\begin{array}{l}\text { Does + litter } \\
\text { emissions } \\
\text { (g/doe.day) }\end{array}$ & $\begin{array}{c}\text { Fattening } \\
\text { emissions }{ }^{\mathrm{A}} \\
\text { (g/fattener.day) }\end{array}$ & $\begin{array}{r}\text { Rabbit meat } \\
(\mathrm{g} / \mathrm{kg} \mathrm{LW})\end{array}$ \\
\hline \multicolumn{7}{|c|}{ Slurry system } \\
\hline $\mathrm{NH}_{3}$ & 240 & 793 & 1033 & 1.60 & 0.25 & 11.29 \\
\hline $\mathrm{N}_{2} \mathrm{O}$ & 0 & 0 & 0 & 0.00 & 0.00 & 0.00 \\
\hline Manure $\mathrm{CH}_{4}$ & 354 & 922 & 1276 & 2.40 & 0.28 & 13.95 \\
\hline Enteric $\mathrm{CH}_{4}$ & 113 & 237 & 350 & 0.51 & 0.09 & 3.83 \\
\hline \multicolumn{7}{|c|}{ Deep-pit system } \\
\hline $\mathrm{NH}_{3}$ & 290 & 958 & 1248 & 1.93 & 0.30 & 13.65 \\
\hline $\mathrm{N}_{2} \mathrm{O}$ & 4 & 12 & 16 & 0.02 & 0.00 & 0.17 \\
\hline Manure $\mathrm{CH}_{4}$ & 354 & 922 & 1276 & 2.40 & 0.28 & 13.95 \\
\hline Enteric $\mathrm{CH}_{4}$ & 113 & 237 & 350 & 0.51 & 0.09 & 3.83 \\
\hline
\end{tabular}

\footnotetext{
A.e. after weaning.
} 
Moreover, in our model we only considered the influence of manure management system and slurry removal frequency. However, many other factors (temperature, ventilation rate, feed composition) are known to influence gas emissions (Méda et al. 2011) and could be added to our modelling approach in order to decrease uncertainties in our simulation results. Yet, as stated earlier, very few data are available in the literature concerning rabbit production and new experiments should be designed in order to better assess the influence of these factors on emissions.

\section{Conclusions}

This paper presents an original simulation model to study the environmental impact of rabbit production at the farm level. It should help investigate the influence of farming practices (animal feeding, reproduction and manure management) on several environmental criteria such as manure production or $\mathrm{NH}_{3}$ and GHG emissions $\left(\mathrm{N}_{2} \mathrm{O}\right.$ and $\left.\mathrm{CH}_{4}\right)$. Moreover, it focuses both on $\mathrm{N}$ and $\mathrm{P}$ to prevent pollution swapping. Even though the model considers the influence of manure management system on gas emissions, further improvements are required to improve the accuracy of the model and reduce uncertainties in simulation results. Yet, these improvements will only be possible with the acquisition of experimental knowledge specific to rabbit farms (emission factors, controlling factors). Finally, in order to design more sustainable livestock-farming systems, this model should be combined with an economical approach in order to identify the best farming practices both on environmental and economic points of view.

\section{Acknowledgements}

This work was funded by a grant from the Animal Physiology and Livestock Farming Systems division (PHASE) of the French National Institute for Agricultural Research (INRA). The authors are thankful to Vincent Loussouarn (EUROLAP society) who provided data to adjust the growth model of fatteners and to Guillaume Coutelet (French Technical Institute for Poultry Production, ITAVI) for his help with the technical-economic data used in the simulation.

\section{References}

Belenguer A, Fondevila M, Balcells J, Abecia L, Lachica M, Carro MD (2011) Methanogenesis in rabbit caecum as affected by the fermentation pattern: in vitro and in vivo measurements. World Rabbit Science 19, 75-83. doi:10.4995/wrs.2011.826

Bouwman AF, Van Vuuren DP, Derwent RG, Posch M (2002) A global analysis of acidification and eutrophication of terrestrial ecosystems. Water, Air, and Soil Pollution 141, 349-382. doi:10.1023/A:1021398 008726

Calvet S, Estellés F, Hermida B, Blumetto O, Torres AG (2008) Experimental balance to estimate efficiency in the use of nitrogen in rabbit breeding. World Rabbit Science 16, 205-211.

Calvet S, Cambra-López M, Estellés F, Torres AG (2011) Characterization of the indoor environment and gas emissions in rabbit farms. World Rabbit Science 19, 49-61. doi:10.4995/wrs.2011.802

Chardon X, Rigolot C, Baratte C, Espagnol S, Raison C, Martin-Clouaire R, Rellier J-P, Le Gall A, Dourmad JY, Piquemal B, Leterme P, Paillat JM, Delaby L, Garcia F, Peyraud JL, Poupa JC, Morvan T, Faverdin P (2012) MELODIE: a whole-farm model to study the dynamics of nutrients in dairy and pig farms with crops. Animal 6, 1711-1721. doi:10.1017/ S1751731112000687
CORPEN (1999) Estimation des rejets d'azote et de phosphore par les élevages cunicoles Comité d'Orientation pour des Pratiques Agricoles Respectueuses de l'Environnement.

EEA (2013) 'EMEP/EEA air pollutant emission inventory guidebook 2013 technical chapter 3.B manure management.' (European Environment Agency: Copenhagen) Available at http://www.eea.europa.eu/ publications/emep-eea-guidebook-2013 [Verified 12 September 2014]

European Commission (2003) Integrated Pollution Prevention and Control (IPPC) - reference document on best available techniques for intensive rearing of poultry and pigs. (European Commission: Brussels) Available at http://eippcb.jrc.ec.europa.eu/reference/BREF/irpp_bref_0703.pdf [Verified 12 September 2014]

FAO (2006) 'Livestock long shadow. Environmental issues and options.' (FAO: Rome)

Ferrer P, Cambra-López M, Borrás M, Cerisuelo A, Moset V (2011) Evaluación in vitro de la actividad metanogenica y caracterización físico-quimica de la gallinaza y el estiercol de conejo. In 'XIV jornadas sobre producción animal, Tomo II, Zaragoza, Spain, 17-18 May'. (Ed. AIDA) pp. 860-862.

Feugier A, Fortun-Lamothe L (2006) Extensive reproductive rhythm and early weaning improve body condition and fertility of rabbit does. Animal Research 55, 459-470. doi:10.1051/animres:2006025

Fortun L, Prunier A, Lebas F (1993) Effects of lactation on fetal survival and development in rabbit does mated shortly after parturition. Journal of Animal Science 71, 1882-1886.

Franz R, Soliva CR, Kreuzer M, Hummel J, Clauss M (2011) Methane output of rabbits (Oryctolagus cuniculus) and guinea pigs (Cavia porcellus) fed a hay-only diet: implications for the scaling of methane production with body mass in non-ruminant mammalian herbivores. Comparative Biochemistry and Physiology. Part A, Molecular \& Integrative Physiology 158, 177-181. doi:10.1016/j.cbpa.2010.10.019

Hassouna M, Robin P, Charpiot A, Edouard N, Méda B (2013) Infrared photoacoustic spectroscopy in animal houses: effect of non-compensated interferences on ammonia, nitrous oxide and methane air concentrations. Biosystems Engineering 114, 318-326. doi:10.1016/j.biosystemseng. 2012.12.011

IPCC (2006) '2006 IPCC guidelines for national greenhouse gas inventories. Prepared by the National Greenhouse Gas Inventories Programme. In 'Agriculture, forestry and other land use. Vol. 4. Chapter 10. Emissions from livestock and manure management'. (Eds HS Eggleston, L Buendia, K Miwa, T Ngara, K Tanabe) (IGES: Japan)

IPCC (2007) 'Climate change 2007: synthesis report.' (Intergovernmental Panel on Climate Change: Geneva)

ITAVI (2013) 'Gestion technico-economique des éleveurs de lapins de chair: programmes RENACEB et RENALAP - résultats 2012.' (ITAVI: Paris).

Kristensen HH, Wathes CM (2000) Ammonia and poultry welfare: a review. World's Poultry Science Journal 56, 235-245. doi:10.1079/ WPS20000018

Levasseur P, Charles M, Le Bris B, Boulestreau AL, Landrain P, Athanase N (2007) Comparaison de méthodes d'estimation des rejets d'azote, de phosphore et de potassium en élevage de porc. In '39èmes Journées de la Recherche Porcine, Paris, France, 6-8 February'. (Ed. IFIP) pp. 1-6.

Maertens L (2009) Possibilities to reduce the feed conversion in rabbit production. In 'Giornate di Coniglicoltura ASIC 2009. Forli, Italy, 2-3 April'. pp. 1-10.

Maertens L, Cavani C, Petracci M (2005) Nitrogen and phosphorus excretion on commercial rabbit farms: calculations based on the input-output balance. World Rabbit Science 13, 3-16.

Maertens L, Lebas F, Szendrö Z (2006) Rabbit milk: a review of quantity, quality and non-dietary affecting factors. World Rabbit Science 14, 205-230.

Marounek M, Fievez V, Mbanzamihigo L, Demeyer D, Maertens L (1999) Age and incubation time effects on in vitro caecal fermentation pattern in 
rabbits before and after weaning. Archives of Animal Nutrition 52, 195-201.

Méda B, Hassouna M, Aubert C, Robin P, Dourmad JY (2011) Influence of rearing conditions and manure management practices on ammonia and greenhouse gas emissions from poultry houses. World's Poultry Science Journal 67, 441-456. doi:10.1017/S0043933911000493

Méda B, Robin P, Aubert C, Dourmad JY, Hassouna M (2012) MOLDAVI: a model to predict environmental and economic performances of broiler farming systems. 10th European IFSA symposium - producing and reproducing farming systems: new modes of organization for sustainable food systems of tomorrow, Aarhus, Denmark, 1-4 July. Available at http://www.ifsa2012.dk/downloads/WS6_4/Bretrand_ Meda.pdf [Verified 12 September 2014]

Monteny GJ, Bannink A, Chadwick D (2006) Greenhouse gas abatement strategies for animal husbandry. Agriculture, Ecosystems \& Environment 112, 163-170. doi:10.1016/j.agee.2005.08.015

Nicodemus NCR, Garcia J, De Blas JC (2004) Performance response of doe rabbits to Toyocerin ${ }^{\circledR}$ (Bacillus cereus var. Toyoi) supplementation. World Rabbit Science 12, 109-118. doi:10.4995/wrs.2004.577

Orengo J, Gidenne T (2007) Feeding behaviour and caecotrophy in the young rabbit before weaning: an approach by analysing the digestive contents. Applied Animal Behaviour Science 102, 106-118. doi:10.1016/ j.applanim.2006.03.010

Pascual JJ, Xiccato G, Fortun-Lamothe L (2006) Strategies for doe's corporal condition improvement - relationship with litter viability and career length. In 'Recent advances in rabbit sciences'. (Eds L Maertens, P Coudert) pp. 247-258. (Instituut voor Landbouwen Visserijonder (ILVO): Melle, Belgium)

Piattoni F, Demeyer D, Maertens L (1996) In vitro study of the age-dependent caecal fermentation pattern and methanogenesis in young rabbits. Reproduction, Nutrition, Development 36, 253-261. doi:10.1051/rnd: 19960303
Rigolot C, Espagnol S, Robin P, Hassouna M, Béline F, Paillat JM, Dourmad $\mathrm{J}-\mathrm{Y}$ (2010) Modelling of manure production by pigs and $\mathrm{NH}_{3}, \mathrm{~N}_{2} \mathrm{O}$ and $\mathrm{CH}_{4}$ emissions. Part II: effect of animal housing, manure storage and treatment practices. Animal 4, 1413-1424. doi:10.1017/S17517311100 00509

Rotz CA (2004) Management to reduce nitrogen losses in animal production. Journal of Animal Science 82, E119-E137.

Rotz CA, Corson MS, Dawn S, Chianese DS, Montes F, Hafner SD, Coiner CU (2012) 'The Integrated Farm System Model: reference manual version 3.6.' Available at http://ars.usda.gov/SP2UserFiles/Place/19020000/ifsm reference.pdf [Verified 12 September 2014]

Sise JA, Kerslake JI, Oliver MJ, Glennie S, Butler D, Behrent M, Fennessy PF, Campbell AW (2011) Development of a software model to estimate daily greenhouse gas emissions of pasture-fed ruminant farming systems. Animal Production Science 51, 60-70. doi:10.1071/AN10072

van Milgen J, Valancogne A, Dubois S, Dourmad JY, Sève B, Noblet J (2008) InraPorc: a model and decision support tool for the nutrition of growing pigs. Animal Feed Science and Technology 143, 387-405. doi:10.1016/ j.anifeedsci.2007.05.020

Whyte RT (1993) Aerial pollutants and the health of poultry farmers. World's Poultry Science Journal 49, 139-156. doi:10.1079/WPS19930012

Xiccato G, Trocino A (2010) Energy and protein metabolism and requirements. In 'Nutrition of the rabbit'. 2nd edn. (Eds $\mathrm{C}$ de Blas, J Wiseman) pp. 83-118. (CABI: Wallingford, UK)

Zened A, Meda B, Ponchant P, Wilfart A, Arroyo J, Gidenne T, Brachet A, Combes S, Fortun-Lamothe L (2013) Conséquences d'une restriction alimentaire chez le lapereau sevré sur les impacts environnementaux de la production de viande de lapin. In '15èmes Journées de la Recherche Cunicole. Le Mans, France, 19-20 November’. (Ed. ITAVI) pp. 141-144. (ITAVI: Paris) 